\title{
A. Jenis dan Pembagian Harta
}

Klasifikasi pembagian jenis harta dapat didasarkan dari berbagai segi :

1. Ditinjau dari segi dapat dipindahkan atau tidaknya:

a. Harta bergerak (harta manqul) yaiyu harta yang dapat dipindahkan dari suatu tempat ketempat yang lain. Contohnya seperti motor, mobil, leptop, handphone, dan lainnya.

b. Harta tidak bergerak (harta uqor/ghairul Manaqul), yaitu harta yang tidak dapat dipindahkan dari satu tempat ketempat yang lainnya atau yang dikenal dengan harta tetap. Contohnya seperti rumah, gedung, sawah, sekolah dan lain-lain (Mardani, Hukum bisnis syariah, 2014)

2. Ditinjau dari seg dapat atau tidaknya diganti dengan harta lain yang sama:

a. Harta mitsli, yaitu harta yang dapat diganti dengan harta lainnya yang sama atau dengan kata lain, harta yang jenisnya mudah dicari dipasar, seperti beras rojolele, salak pondoh, mangga arumanis, atau benda yang dapat diukur dengan timbangan.

b. Harta qimi, yaitu harta yang hanya dapat diganti dengan nilai harganya atau harta yng jenisnya tidak mudah dicari dipasar. Seperti karya seni yang berupa lukisan atau gambar ataupun kerajinan tangan uatan orang-orang tertentu

3. Ditinjau dari segi boleh dimanfaatkan dan tidaknya, harta terbagi manjadi dua, yaitu:

a. Harta mutaqawwim, yaitu harta yang dapat dimnfaatkan menurut syarah dan siapa yang merusaknya wajib meggantinya.

b. Harta ghairu mutaqawwim, yaitu harta yang tidak boleh dimanfaatknanya menurut ketentuan syara.

Sebagai contoh perbedaan antara harta mutaqawwir dan harta ghairu mutaqawwir, seperti babi, khamer dan darah yang tidak halal, tidak bisa dijadikan objek transaksi dan 
tidak pula diperbolehkan untuk dimanfaatkan oleh orang muslim, sehingga orang muslim tidak dituntut untuk mengganti kerugian apabila merusaknya. Tetapi menurut ulama Hanafiyah, jika babi itu milik kafir dzimmi, maka orang muslim yang merusaknya wajib membayar ganti rugi karena benda (babi) itu termasuk mutaqawwim bagi kafir dzimmi. Jumhur ulama berpendirian bahwa dalam kasus seorang muslim yang merusak atau melenyapkan babi atau khamer milik kafir dzimmi tidak boleh dituntut ganti rugi karena benda itu tidak bernilai atau dimanfaatkan oleh orang muslim

4. Ditinjau dari segi habis dan tidaknya setelah digunakan atau dipakai:

a. Harta isti'mali (tidak habis pakai), yaitu harta yang apabila digunakan atau dimanfaatkan, harta itu masih utuh, meskipun manfaatnya sudah digunakan, seperti kebun, tanah ladang, lahan pertanian dan lain-lain.

b. Harta istihlaki (habus pakai), yaitu harta yang apabila digunakan atau dimanfaatkan harta itu menjadi habis. Seperti makanan, minuman, minyak, dan lain-lain.

5. Dilohat dari status harta:

a. Harta mamluk, yaitu harta yang telah dimiliki, baik milik perorangan atau milik badan hukum atau milik negara. Harta makmul terbagi menjadi tiga yaitu harta milik sendiri dan harta milik bersama.

b. Harta mubah, yaitu harta yang belum dimiliki seseorang. Seperti mata air, ikan dilaut atau sunagi, burung yang masih diudara, dan sebagainya.

c. Harta mahjur, yaitu harta yang ada karangan syara untuk dimilikinya secara pribadi. Spserti harta wakaf atau harta untuk kepentingan umum. 
6. Dilihat dari segi boleh dibagi atau tidak:

a. Mal qabil li al-qismah (harta yang dapat dibagi), yaitu harta yang tidak dapat menimbulkan kerugian atau kerusakan apabila harta itu dibagi-bagi dan manfaatnya tidak hilang. Seperti gandum, beras, anggur, jeruk, duku, dan lain-lain

b. Mal ghairu qabil li al-qismah (harta yang tidak dapat dibagi), yaitu harta yang dapat menimbulkan kerugian atau kerusakan atau hilang manfaatnya, apabila harta itu dibagibagi. Seperti gelas, meja, kursi, batu permata, danlain-lain

7. Dilihat dari segi berkembang atau tidaknya:

a. Harta al-ashi (asal), yaitu harta yang menghasilkan seperti rumah, tanah, hewan, da pepohonan.

b. Harta al-samar (buah atau hasil), yaitu buah yang dihasilkan oleh suatu harta. Seperti sewa rumah, buah dari pohon, ir susu dari kembing dan sebagainya.

8. Dilihat dari segi pemiliknya :

a. Harta milik pribadi, yaitu harta yang tidak bersekutu dengan yang lain, dan tidak boleh diambil manfaatnya kecuali ada izin dari pemiliknya.

b. Harta milik umum (masyarakat), yaitu harta yang dapat diambil manfaatnya oleh masyarakat secara umum. Seperti sungai, jalan raya, lapangan dan sebagainya.

Terkait harta milik pribadi dan harta milik umum ini bisa berubah status dari milik pribadi menjadi milik umum atau sebaliknya. Perubahan ini dapat dijelaskan sebagai berikut:

a. Harta milik bersama bisa berubah menjadi milik pribadi apabila telah diambil dan dirawatnya dengan baik oleh seseorang . 
b. Harta milik pribadi bisa berubah menjadi milik umum, jika atas kehendak sandiri dari pemiliknya, misalnya seseorang menjadikan hartanya menjadi harta wakaf yang dapat dimanfaatkan untuk kepentingan umat. Disamping itu juga atas kehendak syara; seperti keperluan umat/umum yang mendesak untuk membuat jalan umum atas tanah milik pribadi. Dalam hal ini, pihak pemerintah boleh mempergunakan tanah pribadi (milik rakyat) untuk perluasan jalan tol

\section{B. Fungsi dan Manfaat Harta}

dalam kepemilikan harta disamping untuk kemaslahatan pribadi sebagai pemilik, juga harus mendatangkan manfaat dan maslahah untuk masyarakat umum. Dan tidak laha pentingnya bahwa penggunaan harta dalam ajaran islam harus senantiasa dalam rangka pengabdian dan pendekatan diri kepada Allah swt. Mengapa demikian, karena status harta adalah mutlak milik Allah swt, manusia hanya sebagai bendahara Alah, artinya penggunaan harta harus tunduk dan patuh atas titahnya.

Berangkat dari hal tersebut, maka fungsi dan manfaat harta yang dimiliki oleh manusia dalam islam adalah:

1. Penyempurnaan ibadah madhah, karena keabsahan ibadah dibutuhkan untuk sarana menutup aurat, seperti kain, baju, mukena, dan sebagainya.

2. Untuk memelihara dan memntingkan iman dan taqwa kepada Allah swt, karena kefakiran akan membawa kepada kekufuran.

3. Meneruskan estafet kehidupan generasi akan datang yang lebih kuat, karena Allah swt melarang meninggalkan generasi yang lemah dalam bidang ekonomi.

4. Bekal mencari dan mengembangkan kekayaan dan ilmu yang barokah baik didunia maupun di akhirat. 
5. Mengeseimbangkan kebahagiaan antara dunia dan akhirat

\section{Konsep Dasar Hak Milik}

\section{Pengertian Hak Milik}

Kata milik berasa dari bahasa arab al-milk, berarti sesuatu yang dimiliki (harta). milik juga berarti hubungan seseorang dangan suatu harta benda yang diakui oleh syara', yang menjadikannya mempunyai kekuasaan khusus terhadap harta itu, sehingga ia dapat melakukan tindakan hukum terhadap harta itu, kecuali adanya halangan syara'. Al-milk secara terminologi, yaitu pengkhususan seseorang terhadap suatu benda yang memungkinkannya untuk bertindak hukum terhadap benda itu, selama tidak ada halangan syara'. Contoh halangan syara' misalnya prang tersebut belim cakap bertindak hukum (seperti anak kecil dan orang gila), atau kecakapan hukum hilang, sehingga dalam hal-hal tertentu ia tidak dapat bertindak hukum terkait hak milik. 


\section{Daftar pustaka:}

Drs. Harun, MH, 2017, Fiqh Muamalah, surakarta, Muhammadiyah Universitas Press 25985-EN-sumber-hak-milik-dalam-perspektif-hukum-islam.pdf 